\title{
ANALISIS TENTANG KETENTUAN TINDAK PIDANA PERTANAHAN DALAM KITAB UNDANG-UNDANG HUKUM PIDANA
}

\author{
Oleh: Iwan Setiawan, S.H., M.H. ${ }^{*}$
}

\begin{abstract}
Increased development, so the need for land is increasing as well, while the supply of land is increasingly limited. Such circumstances result in many crimes or violations of the land occurring either falsification of land letters used for its benefit and harm to others, as well as by cheating by benefiting oneself or others by violating rights by selling, exchanging, renting or making debt burden of a people's right to use government or private land, land restrictions. In addition to the crimes against the land, there are also violations and they have been regulated in the Criminal Code solely to secure the welfare of the landowners, therefore in this paper discussing elements and accountability penidanaannya.
\end{abstract}

Keywords: Criminal Acts Land, The Criminal Code

\begin{abstract}
Abstrak
Semakin meningkatnya pembangunan, maka kebutuhan terhadap tanah semakin meningkat pula, sedang persediaan tanah semakin terbatas. Keadaan yang demikian berakibat banyaknya kejahatan maupun pelanggaran terhadap tanah terjadi baik itu pemalsuan surat-surat tanah yang dipergunakan untuk kepentingannya dan merugikan bagi orang lain, juga dengan menipu dengan menguntungkan diri sendiri atau orang lain dengan melawan hak dengan jalan menjual, menukarkan, menyewakan atau menjadikan tanggungan utang sesuatu hak rakyat dalam memakai tanah pemerintah atau partikelir, pembatasan tanah. Selain kejahatan terhadap tanah, terdapat juga pelanggaran-pelanggaran dan semuanya itu telah diatur dalam KUHP yang semata-mata untuk menjamin kesejahteraan dari pada pemilik tanah, maka dari itu dalam makalah ini membahas unsur-unsur dan pertanggung-jawaban pemidanaannya.
\end{abstract}

Kata Kunci: Tindak Pidana Tanah, Kitab Undang-Undang Hukum Pidana

\section{Pendahuluan}

Permasalahan di bidang hukum seolah menjadi salah satu persoalan yang tidak pernah surut dalam kehidupan bermasyarakat, berbangsa dan bernegara. Seiring meningkatnya permasalahan di bidang hukum maka meningkat pula kajian

\footnotetext{
* Dosen Tetap Fakultas Hukum Universitas Galuh
} 
yuridis yang bertujuan menggali informasi terkait berbagai masalah dari perspektif hukum dan perundang-undangan yang ada.

Tinjauan yuridis yang menggunakan dasar-dasar hukum, teori dan perundang-undangan dalam mengkaji suatu masalah, menjadi sangat penting dalam menemukan solusi hukum atas suatu masalah yang hendak dikaji. Hal ini juga sejalan dengan pendapat yang dikemukakan oleh Paul Scholten bahwa,"hukum itu ada namun harus ditemukan" (Satjipto Rahardjo, 2006: 124).

Konsepsi penemuan hukum, menurut Paul Scholten dapat dilakukan melalui penalaran logis, interpretasi-interpretasi atau penafsiran- penafsiran, dikemukakan oleh Friedman bahwa proses penemuan hukum tersebut tidak terbatas pada pemahaman atas peraturan atau teks-teks dokumen dan "looking towards last things, consequences fruits" (Satjipto Rahardjo, 2006: 139). bahkan Roscoe Pound menolak studi hukum sebagai studi tentang peraturan- peraturan, melainkan keluar dari situ dan melihat efek dari hukum dan bekerjanya hukum.

Permasalahan di bidang hukum sudah banyak dikaji secara yuridis termasuk salah satunya permasalahan dalam tindak pidana. Permasalahan yang sering muncul dalam penyelesaian suatu masalah hukum khususnya menyangkut tindak pidana adalah ketidakadilan dan kepastian hukum. Penyelesaian suatu perkara pidana seringkali menimbulkan polemik atau ketidakpuasan di kalangan pencari keadilan karena putusan hakim dinilai merugikan salah satu pihak yang berperkara di pengadilan. Demikian halnya dalam konteks kepastian hukum, yang seringkali memunculkan permasalahan akibat lemahnya peraturan perundangundangan yang ada dalam mengatur suatu penyelesaian masalah hukum khususnya dalam perkara tindak pidana.

Salah satu permasalahan yang sering terjadi dalam kehidupan bermasyarakat dalam perspektif tindak pidana adalah permasalahan yang menyangkut dengan tanah, yang cenderung bermetamorfosis dalam kehidupan sosial masyarakat. Tanah tidak lagi sekedar dipandang sebagai masalah agraria semata yang selama ini diidentikkan sebagai pertanian belaka, melainkan telah berkembang, baik manfaat maupun kegunaannya, sehingga terjadi dampak negatif yang semakin kompleks, bahkan tanah sering menimbulkan guncangan dalam masyarakat serta sendatan dalam pelaksanaan pembangunan.

Tanah merupakan salah satu kebutuhan hidup manusia yang sangat mendasar, dapat dikatakan hampir kegiatan hidup manusia baik secara langsung 
maupun tidak langsung selalu berhubungan dengan tanah, hubungan ini terjadi oleh karena tanah itu memberi penghidupan bagi manusia dalam hal tempat tinggal, sebagai mata pencaharian seperti pertanian, perkebunan, perumahan, perkantoran bahkan industri yang semakin meningkat dari tahun ke tahun (Soekanto, 1981: 91).

Ketidakseimbangan antara jumlah dan luas tanah yang tersedia yang tidak bertambah dengan kebutuhan penggunaan masyarakat yang semakin meningkat menyebabkan tanah mempunyai arti yang sangat penting, sehingga campur tangan negara melalui aparatnya dalam tatanan hukum pertanahan merupakan hal yang mutlak untuk diadakan.

Jumlah dan luas tanah yang tidak seimbang dengan kebutuhan masyarakat akan melahirkan kompetisi antar sesama manusia untuk memperoleh tanah hal ini mengakibatkan banyak timbulnya konflik agraria.

Sebagai program prioritas, penyelesaian kasus-kasus pertanahan senantiasa menjadi perhatian seluruh jajaran Badan Pertanahan Nasional RI di tingkat pusat, Kantor Wilayah Propinsi maupun Kantor Pertanahan Kabupaten/Kota seluruh Indonesia. Hasil rekaman Konsorsium Pembaruan Agraria (KPA) dalam kurun waktu 11 tahun sejak 2004 hingga 2015 telah terjadi 1.772 konflik di Indonesia. Konflik tersebut mencapai luas wilayah 6.942.381 hektare yang melibatkan hingga 1.085.817 kepala keluarga. Pada tahun 2015 terjadi 93 kasus kekerasan. Jumlah tersebut terdiri 3 kasus yang melibatkan perusahaan, polisi (21 kasus), TNI (21 kasus) pemerintah (10 kasus), dan preman (8 kasus). Dari 93 kasus kekerasan yang terjadi, sebanyak 446 orang menjadi korban kekerasan. Jumlah tersebut terdiri dari 5 orang tewas, 39 tertembak aparat, 124 orang dianiaya atau mengalami luka-luka, dan 278 orang dikriminalisasi (http://www.republika.co.id/berita/koran/podium/16/01/27/01lq8a5reforma-agraria-harus-serius).

Konflik pertanahan dapat terjadi antara orang perseorangan, badan hukum atau lembaga yang tidak berdampak luas secara sosio-politis. Penekanan yang tidak berdampak luas inilah yang membedakan definisi sengketa pertanahan dengan definisi konflik pertanahan, sengketa tanah dapat berupa sengketa administratif, sengketa perdata, sengketa pidana terkait dengan pemilikan, transaksi, pendaftaran, penjaminan, pemanfaatan, penguasaan dan sengketa hak ulayat. 


\section{Pembahasan}

Tanah termasuk dalam penggolongan benda tidak bergerak yang dapat diberikan hak di atasnya. Kepemilikan hak atas tanah dapat diperolesh dengan cara jual beli, hibah, tukar menukar, pemisahan dan pembagian biasa, pemisahan dan pembagian harta warisan, penyerahan hibah wasiat, hipotik, credit verband.

Kebijakan di bidang pertanahan sebagai kebijakan sosial harus sejalan dengan kebijakan kriminal untuk mencegah timbulnya penyimpanganpenyimpanagan dalam pelaksanaan kebijakan sosial tersebut. Kebijakan kriminal akan berfungsi sebagai pengaman, pencegah sekaligus penindak munculnya penyimpangan

Hukum pidana sebagai kebijakan kriminal merupakan ultimum remidium, yang berarti merupakan sarana terakhir, penyelesaian terakhir setelah saranasarana lain yang digunakan tidak mampu menyelesaikannya. Sifat hukum pidana yang memaksa dapat menjadi efek penjera dan penggentar bagi pelaku dan atau calon pelaku. Sanksi pidana merupakan salah satu sarana paling efektif yang digunakan untuk menanggulangi kejahatan, namun pidana bukan sarana satusatunya, sehingga apabila perlu dapat digunakan kombinasi dengan upaya sosial lainnya.

Adapun pasal-pasal dalam Kitab Undang-undang Hukum Pidana (selanjutnya disingkat KUHP) yang berkenaan tentang tindak pidana pertanahan diantaranya yaitu pasal $385 \mathrm{KUHP}$, yang terdapat pada buku ke II, bab XXV tentang kejahatan penipuan. Pasal 385 KUHP berbunyi; diancam dengan pidana penjara paling lama 4 (empat) tahun :

ke-1 barangsiapa dengan maksud menguntungkan diri sendiri atau orang lain secara melawan hukum, menjual, menukarkan atau membebani dengan crediet verband sesuatu hak tanah Indonesia, sesuatu gedung, bangunan, penanaman atau pembenihan di atas tanah dengan hak Indonesia, padahal diketahui bahwa yang mempunyai atau turut mempunyai hak atasnya adalah orang lain ;

ke-2 barangsiapa dengan maksud yang sama menjual, menukarkan atau membebani dengan crediet verband sesuatu hak tanah Indonesia yang telah dibebani crediet verband, atau sesuatu gedung, bangunan, penanaman atau pembenihan di atas tanah yang juga telah dibebani 
demikian, tanpa memberitahukan tentang adanya beban itu kepada pihak yang lain ;

ke-3 barangsiapa dengan maksud yang sama mengadakan crediet verband mengenai sesuatu hak tanah Indonesia, dengan menyembunyikan kepada pihak lain, bahwa tanah yang berhubungan dengan hak tadi sudah digadaikan.

ke-4 barangsiapa dengan maksud yang sama, menggadaikan atau menyewakan tanah dengan hak Indonesia, padahal diketahui bahwa orang lain yang mempunyai atau turut mempunyai hak atas tanah itu.

ke-5 barangsiapa dengan maksud yang sama, menjual atau menukarkan tanah dengan hak Indonesia yang telah digadaikan, padahal tidak diberitahukan kepada pihak yang lain, bahwa tanah itu telah digadaikan.

ke-6 barangsiapa dengan maksud yang sama, menjual atau menukarkan tanah dengan hak Indonesia untuk suatu masa, padahal diketahui, bahwa tanah itu telah disewakan kepada orang lain untuk masa itu juga.

Sianturi, (1989: 661) menjelaskan bahwa "barangsiapa" dalam pasal ini sesuai dengan pasal 9 Undang-Undang Republik Indonesia Nomor 5 Tahun 1960 (selanjutnya disingkat UUPA), maka yang dimaksud dengan "barangsiapa" pada sub ayat ke-1 sd ke-6 tersebut hanyalah warga negara Indonesia.

Selanjutnya Sianturi (1989: 616-617) menjelaskan bahwa maksud dari "dengan maksud menguntungkan diri sendiri atau orang lain", yaitu bahwa delik ke-1 sd ke-6 adalah delik sengaja yang ternyata dengan pencantuman "dengan maksud". Karena penempatannya di depan, maka semua unsur berikutnya dicakupi oleh dolus tersebut. Dengan maksud di sini memperlihatkan kehendak dari sipelaku untuk menguntungkan diri sendiri dan di lain fihak memperlihatkan pengetahuan atau kesadaran sipelaku bahwa ia melakukan tindakan memaksa dan seterusnya. Jadi dengan maksud menguntungkan diri sendiri atau orang lain secara melawan hukum berarti: si pelaku mengetahui bahwa untuk menguntungkan diri sendiri / orang lain tersebut adalah suatu tindakan yang bertentangan dengan hukum atau dengan hak orang lain. Kalau sipelaku tidak ada kehendak untuk menguntungkan diri sendiri atau orang lain, maka pasal yang lebih tepat diterapkan adalah pasal 335. Bahkan jika sipelaku yakin atau mengira bahwa ia berhak untuk menguntungkan diri sendiri / orang lain (misalnya sipelaku 
yakin bahwa bahwa barang itu adalah miliknya atau milik temannya yang baru saja hilang), maka unsur ini tidak terpenuhi dan karenanya penerapan pasal ini tidak tepat. Bahwa maksud sipelaku adalah untuk menguntungkan diri sendiri / orang lain, harus terbukti. Tetapi akah harus terbukti pula bahwa yang diperas itu harus merasa dirugikan, tidak dipersoalkan. Namun jika yang diperas itu memang merasa dirugikan, maka hal ini dapat digunakan untuk memperkuat maksud si pelaku.

Komentar atau penjelasan Sianturi terhadap unsur "dengan maksud hendak menguntungkan diri sendiri atau orang lain secara melawan hukum" juga terdapat dalam pasal 368 KUHP.

Penggunaan istilah "dengan maksud" yang ditempatkan di awal perumusan berfungsi rangkap, yaitu baik sebagai pengganti dari kesengajaan maupun sebagai pernyataan tujuan. Sebagai unsur sengaja, maka si pelaku menyadari/ menghendaki suatu keuntungan untuk diri sendiri/ orang lain. Bahkan dia juga menyadari ketidakberhakannya atau suatu keuntungan tersebut. Menyadari pula bahwa sarana yang digunakan adalah suatu kebohongan atau merupakan alat untuk memberdayakan, demikian juga ia harus menyadari tentang tindakannya yang berupa menggerakkan tersebut. Dalam fungsinya sebagai tujuan, berarti tidak harus selalu menjadi kenyataan keuntungan yang diharapkan itu. Yang penting ialah, adakah ia pada waktu itu mengharapkan suatu keuntungan ? Bahwa mungkin yang sebaliknya yang terjadi, misalnya sesuatu barang yang diberikan itu kemudian mengakibatkan bencana bagi sipelaku / orang lain, tidak dipersoalkan.

Sementara itu Anwar (1982: 32 dan 43) menjelaskan bahwa maksud ditujukan pada menguntungkan diri sendiri atau orang lain yakni Apabila terdapat dua orang melakukan perbuatan paksaan secara bersama, kejahatan ini berlaku terhadap dua orang itu, meskipun yang seorang mempunyai maksud menguntungkan diri sendiri yang lain untuk menguntungkan orang lain. Atas hal ini tidak dapat dianggap, bahwa kedua orang tersebut melakukan kejahatan yang berlainan atau bahwa salah seorang tidak melakukannya, karena mereka mempunyai perbedaan pendapat terhadap keuntungan yang dikehendaki. Tetapi keuntungan yang sama itu terletak didalam maksud.

Tidak diisyaratkan, bahwa tujuan yang dikehendaki diperoleh. Cukup ia melakukan perbuatannya untuk memperolehnya, yaitu penyerahan barang. Juga 
tidak perlu apa yang dikehendaki itu benar-benar melawan hukum. Cukup bahwa tujuannya dapat memberikan keuntungan dan menganggap, bahwa tujuan yang dikehendaki itu adalah melawan hukum. Apabila seseorang menganggap, bahwa perbuatan itu akan memberikan keuntungan yang bersifat melawan hukum kepada orang itu, dan kemudian orang itu melakukan perbuatan itu, maka ia mempunyai maksud untuk menguntungkan diri sendiri secara melawan hukum.

Apakah sesuatu menguntungkan? Hal ini pada umumnya tergantung pada pelakunya. Apakah perbuatan itu akan membawa pelaku kedalam kondisi yang lebih baik. Tetapi menguntungkan tidak terbatas pada memperoleh kekayaan atau menghapuskan hutang belaka, atau tidak pada memperoleh setiap keuntungan yang dihubungkan dengan perbuatan paksaan itu atau yang berhubungan dengan akibat perbuatn paksaan, tetapi lebih luas, bahkan memperoleh pemberian barang yang dikehendaki dan yang oleh orang lain dianggap tidak bernilai termasuk juga pengertian menguntungkan.

Dengan maksud diartikan tujuan terdekat. Bila pelaku masih membutuhkan tindakan lain untuk mencapai keuntungan itu, maka unsur maksud belum dapat terpenuhi. Maksud itu harus ditujukan kepada menguntungkan dengan melawan hukum, hingga pelaku harus mengetahui, bahwa keuntungan yang menjadi tujuannya itu harus bersifat melawan hukum.

Soesilo (1984: 28-34) menjelasakan bahwa dalam pengertian hukum pidana atau juridis-strafrechtelijk "kesalahan" itu dapat berupa dengan dikehendaki, dimaksud atau dengan sengaja, ataupun karena suatu kelalaian, kurang hati-hati. Kata "sengaja" yang berarti pula opzet (dolus) maksudnya "tahu dan dimaksud ( willens en wetens).

Dalam teorinya bentuk "sengaja" (opzet/dolus) itu ada tiga macam, yaitu :

1. Sengaja sebagai maksud/tujuan (oogmerk), misalnya : A hendak membunuh musuhnya. Tujuan atau maksud-nya ialah membunuh musuh itu, bukan orang lain ; apabila ia jadi membunuh, maka pembunuhan itu telah ia lakukan dengan sengaja sebagai maksud (oogmerk).

2. Sengaja dengan kesadaran pasti akan terjadi (zekerheidsbewustzijn), misalnya : A bermaksud akan membunuh $\mathrm{B}$, dibelakang $\mathrm{B}$ berdiri $\mathrm{C}$; $\mathrm{A}$ tahu atau sadar, bahwa jika ia menembak $B$ pasti akan mengenai pula $C$, tokh tembakan itu dilepaskannya. Dalam hal ini $A$ telah berbuat pembunuhan terhadap B yang dilakukan dengan sengaja sebagai maksud (oogmerk), 
sedangkan terhadap $\mathrm{C}$ ia telah berbuat pembunuhan yang dilakukan dengan sengaja dengan kesadaran pasti akan terjadi (zekerheidsbewustzijn).

3. Sengaja dengan kesadaran mungkin akan terjadi (mogelijkheidsbewustzijn) atau juga bisa disebut sengaja bersyarat (dolus eventualis/voorwaardelijk opzet) misalnya : A bermaksud membunuh dengan menembak $B$ yang berdiri di tempat dimana banyak orang berjalan mondar-mandir, sehingga apabila tembakan itu dilepaskan, besar kemungkinannya (tidak pasti) akan mengenai salah seorang yang mondar-mandir itu. Jika A tokh memaksakan maksudnya akan membunuh $B$ dan melepaskan tembakan tersebut dan mengenai salah seorang yang berjalan mondar-mandir di situ, maka $A$ telah membunuh orang itu dengan sengaja dengan kesadaran mungkin akan terjadi (mogelijkheidsbewustzijn) atau juga bisa disebut sengaja bersyarat (dolus eventualis/voorwaardelijk opzet).

Pada hakekatnya jarak antara "karena salahnya" (culpa) dengan "sengaja dengan kesadaran mungkin akan terjadi (mogelijkheidsbewustzijn) atau juga bisa disebut "sengaja bersyarat" (dolus eventualis/voorwaardelijk opzet) itu tidak jauh, dan amat sulit untuk memberi batas yang tegas. Seorang akhli hukum mencoba merumuskan garis perbatasan itu misalnya sebagai berikut : "Apabila pembuat lebih menghendaki terjadinya suatu akibat yang dimaksud beserta akibat lain yang tidak dimaksud, daripada sama sekali tidak berbuat, maka di sini adalah sengaja dengan kesadaran mungkin terjadi, sedangkan apabila pembuatnya lebih menghendaki sama sekali tidak berbuat dari pada terjadinya akibat yang dikehendaki beserta akibat yang tidak dikehendaki, itu adalah karena kesalahannya (schuld/culpa). Dengan perumusan inipun persoalan tidak menjadi mudah, akhirnya hakim yang berkepentinganlah, yang mempunyai suara terakhir untuk menentukannya.

Adapun maksud "secara melawan hukum" dijelaskan oleh Sianturi (1989: 661; 617), bahwa ditentukannya unsur sifat melawan hukum dari tindakan ini secara formal berarti si petindak tiada hak untuk menguntungkan dirinya sendiri / orang lain dengan cara yang dicantumkan di pasal ini. Dan ditentukannya sifat melawan hukum secara material, berarti sipetindak juga tiada hak melakukan tindakan menjual, menukar, membebani dengan suatu "pinjaman", menyewakan atau menggadaikan "tanah" tersebut. Unsur sifat melawan hukum-nya secara tegas dicantumkan di pasal ini, yang dengan demikian harus dibuktikan bahwa 
maksudnya untuk menguntungkan diri tersebut adalah bersifat melawan hukum, kendati tidak dipermasalahkan. Tetapi juga bahwa tindakan sipelaku untuk memaksa seseorang dengan kekerasan dan seterusnya adalah bersifat melawan hukum, harus juga dapat dibuktikan jika dipermasalahkan oleh pihak terdakwa.

Unsur sifat melawan hukum secara formal di sini ditujukan kepada menguntungkan diri sendiri atau orang lain. Secara formal berarti ditentukan secara tegas. Berarti pula harus dibuktikan walaupun mungkin tidak dpersoalkan oleh fihak terdakwa. Dalam hal ini harus dibuktikan bahwa si terdakwa / orang lain itu tiada haknya untuk mendapatkan keuntungan yang ia harapkan. Dalam penerapan unsur ini, tidak dipersyaratkan bahwa fihak korban juga telah dirugikan secara melawan hukum. Karena kita menganut sifat melawan hukum yang material, maka juga apabila dipersoalkan, harus dapat membuktikan bahwa tindakan terdakwa adalah bersifat melawan hukum. Misalnya : menggerakkan seseorang lain supaya orang itu memberikan sumbangan-wajib untuk suatu yayasan tertentu, padahal untuk digunakan sendiri.

Anwar (1982: 43) menjelaskan Syarat dari melawan hukum harus selalu dihubungkan dengan alat-alat penggerak (pembujuk) yang dipergunakan. Sebagaimana dketahui melawan hukum berarti bertentangan dengan kepatutan yang berlaku didalam kehidupan masyarakat. Suatu keuntungan bersifat tidak wajar atau tidak patut menurut pergaulan masyarakat dapat terjadi, apabila keuntungan ini dperoleh karena penggunaan alat-alat penggerak atau pembujuk, sebab pada keuntungan ini masih melekat kekurang-patutan dari alat-alat penggerak/pembujuk yang dipergunakan untuk memperoleh keuntungan itu. Jadi ada hubungan kausal antara penggunaan alat-alat penggerak/pembujuk dan keuntungan yang diperoleh. Meskipun keuntungan itu mungkin bersifat wajar, namun apabila diperoleh dengan alat-alat penggerak/pembujuk tersebut di atas, tetap keuntungan itu akan bersifat melawan hukum.

Lamintang dan Djisman (1990; 240-241) menjelaskan bahwa yang dimaksud dengan "menggadaikan atau menyewakan" yaitu kejahatan-kejahatan yang menyangkut tanah seperti yang diatur di dalam pasal ini oleh IImu Pengetahuan Hukum Pidana disebut "stellionaat". Ketentuan ini adalah untuk melindungi hak atas tanah yang dimiliki oleh penduduk asli berdasarkan Hukum Adat ataupun bangunan-bangunan atau tanaman-tanaman di atas tanah semacam itu. Sungguhpun benar, bahwa setelah berlakunya UUPA, para camat 
itu ditunjuk sebagai Pejabat Pembuat Akta Tanah, sehingga seharusnya semua tindakan hukum yang menyangkut tanah itu dilakukan di depan camat setempat, akan tetapi didalam praktek banyak terjadi, bahwa hingga kinipun orang masih melakukan jual beli tanah di bawah tangan, bahkan dengan disaksikan oleh para pamong desa, umumnya dengan alasan "untuk sementara" sebelum menghadap camat untuk dilakukan jual beli secara resmi.

Sebelum tahun 1960 memang tidak ada satu peraturan yang berlaku secara umum di seluruh Indonesia tentang bagaimana orang Indonesia itu harus memindah tangankan tanah milik adatnya secara sah, dan karenanya cara tersebut diserahkan kepada Hukum Adat setempat dan umumnya dilakukan didepan Kepala Desa, walaupun cara itu sebenarnya adalah tidak diisyaratkan secara mutlak. Setelah tahun 1960 sudah jelas jual beli tanah secara itu adalah tidak sah. Di daerah pedalaman di desa-desa umumnya orang menganggap bahwa apa yang disebut "girik", "letter C" atau "surat pipil" itu adalah "bukti pemilikan tanah" yang sah., padahal sesungguhnya adalah tidak demikian. Suratsurat semacam itu hanyalah merupakan "tanda wajib pajak" dalam arti, bahwa orang yang namanya disebutkan di dalam surat semacam itu adalah orang yang wajib membayar pajak tanah. Ini tidak berarti bahwa orang yang membayar pajak itu adalah orang yang mempunyai hak milik atas tanah yang pajak tanahnya ia bayar itu.

Sianturi (1989; 660, 662) menjelaskan bahwa delik ini sering disebut sebagai stellionat yang berasal dari bahasa Latin, yang artinya kebohongan dalam perdagangan, kebohongan dalam pembebanan, penghipotikan, pemborg-an,dan lain sebagainya, atau juga kebohongan dalam suatu persetujuan. Pasal ini menghubungkan perbuatan kebohongan / curang itu dengan hak atas sebidang tanah.

Tindakan yang terlarang dalam pasal 385 terdiri atas 6 golongan, yaitu :

ke-1 : Menjual, menukar atau membebani dengan suatu pinjaman sebidang tanah (dengan hak menurut UUPA), bangunan, dan sebagainya, padahal ia mengetahuii adanya hak orang lain di atas tanah tersebut.

ke-2 : Menjual, menukar atau membebani dengan suatu pinjaman sebidang tanah (dengan hak menurut UUPA), bangunan, dan sebagainya, padahal tanah tersebut sebelumnya sudah dibebankan dengan suatu 
pinjaman. Dengan perkataan lain terjadi dua kali pembebanan untuk sebidang tanah yang sama.

ke-3 : Membebani sebidang tanah (dengan hak menurut UUPA) dengan suatu pinjaman, padahal tanah tersebut sudah digadaikan (dalam hal ini gadai Indonesia).

ke-4: Menggadaikan atau menyewakan sebidang tanah (dengan hak menurut UUPA), padahal ada juga orang lain yang mempunyai atau turut serta mempunyai hak atas tanah tersebut.

ke-5: Menjual atau menukarkan sebidang tanah (dengan hak menurut UUPA), padahal sudah digadaikan sebelumnya.

ke-6: Menyewakan sebidang tanah (dengan hak menurut UUPA) untuk waktu tertentu, padahal telah disewakan sebelumnya untuk waktu yang sama.

Soesilo $(1996: 266,267)$ menjelaskan bahwa kejahatan-kejahatan tersebut didalam pasal ini biasa disebut kejahatan Stellionat, yang berarti "penggelapan hak atas barang-barang yang tidak bergerak" (onroerende goederen), misalnya : tanah, sawah, gedung, dll. Supaya dapat dikenakan pasal ini, maka terdakwa harus telah nyata berbuat hal-hal sebagai berikut:

1. terdakwa ada maksud untuk menguntungkan diri sendiri atau orang lain dengan melawan hukum (secara tidak sah);

2. terdakwa telah menjual ; menukar atau memberati dengan crediet verband hak pakai bumiputera atas tanah milik negara atau tanah milik partikulir, atau gedung, pekerjaan, tanaman atau taburan diatas tanah hak pakai bumiputera.

3. terdakwa mengetahui, bahwa yang berhak atau ikut berhak disitu adalah orang lain;

4. terdakwa tidak memberitahukan kepada pihak lain, bahwa disitu ada crediet verband-nya ;

5. terdakwa tidak memberitahukan kepada pihak lain, bahwa tanah itu sudah digadaikan ;

6. terdakwa telah menggadaikan atau menyewakan tanah orang lain ; 
7. terdakwa telah menjual atu menukarkan tanah yang sedang digadaikan pada orang lain, dengan tidak memberitahukan tentang hal itu kepada pihak yang berkepentingan ;

8. terdakwa telah menyewakan tanah buat selama suatu masa, sedang dketahuinya, bahwa tanah itu sebelumnya telah disewakan kepada orang lain.

Mengenai redaksi "tanah dengan hak Indonesia" dijelaskan oleh Sianturi (1989: 660-661) bahwa pasal ini dibuat pada tahun 1915 dan mulai berlaku tahun 1918, yang penerapannya dikaitkan dengan perundangan di bidang agraria (pertanahan) dan perundangan di bidang hukum dagang dan peminjaman uang. Beberapa perundangan yang berkaitan dengan : Suatu hak penggunaan sebidang tanah oleh rakyat Indonesia di atas tanah-negara (landsdomein) atau tanahpartikulir (particuliere landerijen) antara lain adalah :

1. Agrarische Wet (Stb.1870 no.55 jo pasal 51 Stb.1925 no.447);

2. Domeinverklaring (tersebut pasal 1 Agrarisch Besluit Stb.1870 no.118) ;

3. Algemene Domeinverklaring (Stb.1875 no.119a) ;

4. Domeinverklaring lain-lainnya di luar Jawa ;

5. Peraturan-peraturan pelaksanaan K.B. 16 April 1872 no.29 Stb.1872 no.117;

6. Buku II KUH Perdata sepanjang mengenai bumi dan sebagainya

7. Bepalingen betreffende het Credietverband (KB.6 Juli 1908 no.50, Stb.1908 no.542 jo 1909 no.568).

Peraturan-peraturan di atas telah dicabut dengan Undang-Undang Pokok Agraria No.5 tahun 1960 (UUPA). Karenanya sebagai penyesuaiannya maka perkataan Credietverband pada pasal 385 ini harus dibaca sebagai "pinjaman" dari Bank, sesuai dengan perundangan yang berlaku (termasuk perundangan hipotik). Sedangkan kalimat suatu hak-penggunaan sebidang tanah oleh rakyat Indonesia di atas tanah-negara (landsdomein) atau tanah partikulir harus dibaca sebagai "suatu hak-penggunaan sebidang tanah" sebagaimana diatur dalam UUPA.

Wirjono Projodikoro (1980: 50) menjelaskan bahwa sejak mulai berlakunya Undang-Undang Pokok Agraria (UUPA) tanggal 24 September 1960, "tanah dengan hak pakai" ini harus dibaca "tanah dengan hak milik atau hak guna usaha 
atau hak guna bangunan atau hak pakai" dalam arti yang dimaksudkan dalam UUPA itu.

Selanjutnya Anwar (1982: 55-56) menjelaskan bahwa Pasal ini dimaksudkan untuk melindungi setiap hak atas tanah atau atas gedung, bangunan dan tanaman di atas tanah yang dimiliki oleh warga negara pribumi berdasarkan hukum adat. Tetapi sejak berlakunya UU No.5 tahun 1960 (UUPA) pada tanggal 24 September 1960, semua jenis hak berdasarkan hukum adat maupun KUHDS dihapus dan digantikan dengan 4 macam hak atas tanah yang dapat dimiliki oleh WNI serta badan-badan hukum Indonesia, yaitu :

1. Hak Milik atas tanah ;

2. Hak Guna Bangunan atas tanah ;

3. Hak Guna Usaha atas tanah ;

4. Hak Pakai atas tanah ;

Sedangkan tanah yang tidak dibebani hak-hak itu merupakan yang dikuasai oleh negara. Istilah crediet verband merupakan suatu lembaga dalam hukum adat, yaitu suatu jenis jaminan dalam perjanjian hutang-piutang yang dikuasai oleh hukum adat yang menyangkut pertanahan.

Pada saat sekarang Negara Indoensai memiliki hanya satu peraturan hukum pertanahan yaitu Undang-Undang Nomor 5 Tahun 1960 tentang pokokPokok Agraria (UUPA). Hak-hak yang pada saat berlakunya Undang-Undang ini masih ada harus dikonversi. Dengan demikian istilah-istilah, pengertian-pengertian hukum lama yang masih dpergunakan didalam peraturan-peraturan hukum pidana harus juga diganti dengan yang baru. Sebelum berlakunya UUPA ini timbul banyak sekali masalah mengenai pertanahan. Meskipun pada saat sekarang ini sudah ada UU yang yang melindungi hak-hak atas tanah, tetapi tetap masalah pertanahan masih belum lancar, berhubung pengumuman ketentuan-ketentuan dalam UUPA belum dlaksanakan secara teliti dan tepat.

Redaksi "padahal diketahui bahwa orang lain yang mempunyai atau turut mempunyai hak atas tanah itu" dijelasakn dalam MARI No.42 K/Kr/1965 tanggal 8-1-1966, yaitu suatu tindakan pada umumnya dapat hilang sifatnya sebagai melawan hukum bukan hanya berdasarkan sesuatu ketentuan dalam perundangundangan, melainkan juga berdasarkan azas-azas keadilan atau azas hukum yang tidak tertulis dan bersifat umum, sebagai misalnya 3 faktor :

1. Negara tidak dirugikan ; 
2. Kepentingan umum dilayani ; dan

3. Terdakwa tidak dapat untung.

Pelaku harus mempunyai maksud untuk menguntungkan diri secara melawan hukum, dan adalah tidak perlu adanya pihak lain yang dirugikan. Hakim tidak perlu menerapkan terhadap siapa kerugian itu dibebankan.

Selanjutnya dalam MARI No.167 K/Kr/1980 tanggal 28-8-1981 dijelaskan bahwa kualifikasi tindakan pidana termaksud dalam pasal 385 ke-1 KUHP adalah : "dengan maksud untuk menguntungkan diri sendiri atau orang lain dengan melawan hukum telah menjual hak tanah Indonesia, sedang ia tahu orang lain yang berhak atas tanah tersebut.

Begitu pula dijelaskan dalam MARI No.104 K/Kr/1973 tanggal 28-8-1974 bahwa Meminjam sebidang tanah dari yang berhak guna digarap satu musim, tetapi setelah waktu tiba untuk mengembalikannya pada yang berhak tidak dikembalikannya, malahan dijual musiman kepada orang lain, dipersalahkan melanggar pasal $385 \mathrm{ke}-4 \mathrm{KUHP}$.

\section{Kesimpulan}

Masalah pertanahan di Indonesia telah muncul dalam banyak aspek dengan beragam wujud. Berbagai upaya penyelesaian telah ditawarkan baik melalui musyawarah atau mediasi tradisional maupun mediasi pertanahan yang dibentuk dalam lingkungan Instansi Badan Pertanahan Nasional. Penyelesaian dapat pula dilakukan melalui pendekatan yuridis dengan instrumen perdata, tata usaha negara serta pidana.

Untuk mengatasi tindak pidana pertanahan yang semakin kompleks, pendekatan secara hukum pidana dapat dilakukan dalam kerangka ultimum remidium. Pendekatan secara pidana ini untuk memberikan efek penjera sekaligus efek penangkal. Namun demikian pendekatan secara pidana harus dilakukan secara integral dengan pendekatan sosial mengingat permasalahan pertanahan terkait erat dengan sosio kultur masyarakat.

Meskipun demikian, selain dalam KUHP, masalah tindak pidana pertanahan juga diatur dalam peraturan perundang-undangan di antaranya Undang-undang Nomor 41 Tahun 1999 Tentang Kehutanan sebagaimana telah diubah dengan Undang-Undang Nomor 19 Tahun 2004 tentang Penetapan Peraturan Pemerintah Pengganti Undang-Undang Nomor 1 Tahun 2004 tentang 
Perubahan atas Undang-undang Nomor 41 Tahun 1999 tentang Kehutanan Menjadi Undang-Undang

\section{Daftar Pustaka}

Anwar, Moch, 1982, Hukum Pidana Bagian Khusus - Jilid I, Bandung, Alumni.

Lamintang dan Djisman Samosir, 1990, Hukum Pidana Indonesia, Bandung, Sinar Baru, Cet. Ke-3.

Projodikoro, Wirjono, 1980, Tindak-Tindak Pidana Tertentu Di Indonesia, Bandung, Eresco

Rahardjo, Satjipto, 2006, Penegakan Hukum Suatu Tinjauan Sosiologis, Bandung, Rosdakarya

Sianturi, 1989, Tindak Pidana di KUHP Berikut Uraiannya, Jakarta, Alumni AHAEM-PETEHAEM, cet.ke-2.

Soekanto, 1981, Meninjau Hukum Adat Indonesia, Suatu Pengantar Untuk Mempelajari Hukum Adat,Jakarta, Alumni

Soesilo, 1984, Pokok-pokok Hukum Pidana Peraturan Umum dan Delik-delik Khusus, Bogor, Politea.

\section{Perundang-Undangan}

Undang-Undang Nomor 5 Tahun 1960 tentang pokok-Pokok Agraria (UUPA)

Undang-undang Nomor 41 Tahun 1999 Tentang Kehutanan sebagaimana telah diubah dengan Undang-Undang Nomor 19 Tahun 2004 tentang Penetapan Peraturan Pemerintah Pengganti Undang-Undang Nomor 1 Tahun 2004 tentang Perubahan atas Undang-undang Nomor 41 Tahun 1999 tentang Kehutanan Menjadi Undang-Undang

\section{Referensi Lain}

http://www.republika.co.id/berita/koran/podium/16/01/27/o1lq8a5-reformaagraria-harus-serius pada tanggal 15 Maret 2018 